\title{
Twenty Years of Bologna and a Decade of EHEA: What Is Next?
}

\author{
Sjur Bergan and Ligia Deca
}

\section{A Brief History of Considering the Future}

Considering or raising critical questions about the future of the European Higher Education Area is hardly an original endeavor. In one sense, considerations of the future have been present since the outset. In the Bologna Declaration (Bologna Process 1999), ${ }^{1}$ the Ministers of the then 29 "Bologna countries" referred to consolidating a European area of higher education by the end of the "first decade of the third millennium" by coordinating their policies to reach specified objectives and indicated their intention to meet two years later to assess progress and "the new steps to be taken". The first new countries acceded to the Bologna Process already two years later, at the first Ministerial conference after the adoption of the Bologna Declaration (Bologna Process 2001), and in 2007 the Ministerial communiqué included a section on "Looking forward to 2010 and beyond" as well as a mandate to the BFUG to "consider further how the EHEA might develop after 2010 and to report back to the next ministerial meeting in 2009" (Bologna Process 2007a, paragraph 4).

\footnotetext{
${ }^{1}$ All Declarations and Communiqués of the Bologna Process as well as the web sites of the successive Ministerial conferences are accessible through http://www.ehea.info/pid34363/ ministerial-declarations-and-communiques.html, accessed on November 2, 2017.
}

\author{
S. Bergan ( $\square)$ \\ Education Department, Directorate of Democratic Citizenship and Participation/DG \\ Democracy, Council of Europe, Strasbourg, France \\ e-mail: sjur.bergan@coe.int \\ L. Deca \\ Department of Education and Research, Presidential Administration, Bucharest, Romania \\ e-mail: deca.ligia@gmail.com \\ (C) The Author(s) 2018 \\ A. Curaj et al. (eds.), European Higher Education Area: The Impact of Past \\ and Future Policies, https://doi.org/10.1007/978-3-319-77407-7_19
}




\section{Horizon 2010}

To our knowledge, the first organized consideration of the future of the European Higher Education Area beyond its initial phase ${ }^{2}$ came with the 2007-2009 Bologna work program. The Flemish Community of Belgium and Luxembourg, with Noel Vercruysse and Germain Dondelinger as the prime movers, organized a seminar on "Bologna 2020: Unlocking Europe's Potential - Contributing to a Better World"3 in Ghent on May 19-20, 2008. The seminar included a broad range of presentations by well known "Bologna actors" and was based on a survey of stakeholders carried out by the Academic Cooperation Association as well as a research project coordinated by INCHER, the International Center for Higher Education Research at Kassel University (Kehm et al. 2009). The topics of the research papers that informed the seminar ranged from "European higher education in search of a new legal order" and "student mobility and staff mobility in the EHEA beyond 2010" through "market governance in higher education" and "quality, equity, and the social dimension" to "the Bologna Process toward 2020", "the relevance of higher education", and "European higher education in search of a new institutional order". 4

A month later-on June 24-25, 2008 - the BFUG held an extraordinary meeting in Sarajevo on the same topic. The meeting was unusual in more ways than one: it was held outside of the ordinary series of BFUG meetings, it was the first BFUG meeting that focused on a single topic, with parallel sessions and not just plenaries, and it was the first held outside of the country holding the rotating BFUG Chairmanship as well as the first to be held in a non-EU country. In this sense, this extraordinary meeting anticipated the new governance arrangement adopted by Ministers in 2009, whereby the BFUG would no longer be chaired exclusively by the country holding the EU Presidency but co-chaired by this country and a non-EU country (Bologna Process 2009). The paper presented to this meeting (Bologna Process 2008) reviews all Bologna policy areas and action lines with a view to finalizing the agenda, on the safe underlying assumption that "not all the action lines will have been completed by 2010 " (op. cit.: 1). The paper also considers further possible issues for the Bologna Process, phrased as having to provide "relevant, concrete and operational answers to issues affecting higher education in

\footnotetext{
${ }^{2}$ The term "the end of the first decade of the third millennium" has generally been interpreted as meaning 2010.

${ }^{3}$ http://www.ehea.info/cid103198/seminar-on-bologna-beyond-2010.html, accessed on November 2, 2017. Unfortunately, most of the documents for the seminar are no longer available through this link. The background note and provisional program are available at https://media.ehea.info/file/ 20080313-14-Brdo/27/1/BFUG(SI)13_5b_Ghent_Bologna_Seminar_592271.pdf, accessed on November 2, 2017.

${ }^{4}$ The research papers were published as Kehm et al. (2009). The INCHER link to the publication through https://www.uni-kassel.de/einrichtungen/en/incher/research/projects-completed-up-to2010/the-european-higher-education-area-2010-to-2020.html no longer seems operational (accessed on November 2, 2017).
} 
the second decade of the 21st century" (op. cit.: 1) and underlines that while these challenges tend to be global, the Bologna Process needed to identify a specifically European response. The third part of the document discussed the follow-up structure.

In the paper and the discussion, we can already identify elements that have been a staple of discussions about "the future of Bologna" since then. The tension between focusing on implementation of goals already defined and developing new polices and policy areas, concerns about a "two speed Bologna Process" and the search for viable governance of a loosely organized European process that reconciles all these elements are reflected in the paper. Among the possible new policy areas identified (Bologna Process 2008: 9-14), some have been taken up in subsequent discussions, whereas other have not, and not always for good reason. Globalization, public responsibility, and cultural diversity have all been addressed to some extent. The financing of higher education was a hotly debated topic at the Bucharest Ministerial Conference before Ministers agreed on a formulation (Bologna Process 2012a) and was also the topic of a conference organized by Armenia in September 2011 as part of its co-chairmanship of the BFUG, ${ }^{5}$ but has not been a topic of sustained debate. Issues like institutional diversity and demography have not been pursued, even if both have been important in at least some national contexts.

\section{A Boost at Mid-term}

The next significant debate on the future of the EHEA was, in our judgment, the one held at and leading up to the Yerevan Ministerial conference in 2015. The timing is not surprising, since the Yerevan conference was held at equidistance between the formal launching of the European Higher Education Area in 2010 and the next milestone of 2020 .

At the same time, there was a fairly widespread feeling that the EHEA was losing steam and political interest. The first Ministerial conference after the formal launch of the EHEA was held in Bucharest in April 2012. ${ }^{6}$ Even if the preparations were excellent and the program very interesting, and even if there was considerable discussion at the conference, in particular around the issue of financing, the number of countries that attended at political level ${ }^{7}$ dropped markedly but not dramatically. The list of participants at the Ministerial conferences and hence the exact figures are

\footnotetext{
${ }^{5}$ https://www.ehea.info/cid104241/funding-of-higher-education-international-conference.html, accessed on November 2, 2017.

${ }^{6}$ The authors should declare an interest here: Ligia Deca was Head of the Bologna Secretariat 2010 -12 and one of the main organizers of the Bucharest Ministerial Conference. Sjur Bergan was an active participant, representing the Council of Europe.

${ }^{7}$ Understood as being represented by either a Minister or a Deputy Minister/State Secretary or similar.
} 
not readily available. ${ }^{8}$ Based on the lists of participants we have been able to obtain, which include all conferences except those held in 2001 and 2005, some tendencies may be identified:

- The percentage of countries represented at political level (defined as either Ministers or Deputy Ministers or equivalent ${ }^{9}$ ) has remained at or, for the most part, well over two thirds, ranging from highs of $92.5 \%$ in $2003,89.7 \%$ in 1999 and $89.1 \%$ in 2007 to lows of $72.3 \%$ in 2012 and $66.7 \%$ in 2015 .

- The percentage of countries represented by either their Minister or their Deputy Minister (or equivalent) remained above 85 through 2010 and then dropped as indicated above in 2012 and 2015.

- The percentage of countries represented by their (full) Ministers has evolved somewhat differently. From $69 \%$ in Bologna in 1999, the percentage rose to around 82.5 in 2003 and 2007 and then showed two marked drops: a first, to the 61-63\% range in 2009 and 2010, and then a further marked drop to $38.2 \%$ in 2012 and even further to $31.3 \%$ in 2015 . It is worth noting that the level of Ministerial —or for that matter overall political-representation was not significantly different in 2010 than in 2009 in spite of the symbolic importance of the 2010 conference, which formally launched the European Higher Education Area.

Our findings are summarized in Table 1.

We would make one additional remark on participation. The lists of participants are difficult to obtain and in some cases require further work to identify the position of the Heads of Delegation. Even with a long record of direct involvement with the BFUG, we faced challenges; it seems reasonable to assume that future researchers who have not been directly involved will face even greater challenges. It would seem important that the BFUG take measures to make reliable overviews and statistics available to future researchers.

\footnotetext{
${ }^{8}$ Only the lists for the 2003 and 2007 conferences are accessible through the EHEA web site. In addition, the list for the 1999 Bologna conference is available indirectly because all Heads of Delegation signed the Bologna Communiqué, with their titles.

${ }^{9}$ Some of the decisions on which positions to consider as "equivalent" can, of course, be open to discussion. As examples, the Prefect of the Congregation for Catholic Education (Holy See) and the Swiss Federal Counselor responsible for education have been considered as equivalent to Ministers. Assistant Ministers have been considered equivalent to Deputy Minister even if, in some countries, this is not considered a political function. All countries are for the purposes of the statistics considered as a single delegation even if some countries (Belgium, Germany, the United Kingdom) have during the whole or part of the period had double delegations (in casu, Flemish and French Communities, later also the German community; Federal and Land levels; England/ Wales/Northern Ireland and a separate delegation for Scotland). In cases where a single Head of Delegation was indicated in the list of participants, we considered the level of the Head. In other cases, we considered the highest ranking member - thus if at least one Minister participated, this is counted as Ministerial representation. There may well be slight errors in our judgments but the figures clearly indicate an order of magnitude.
} 


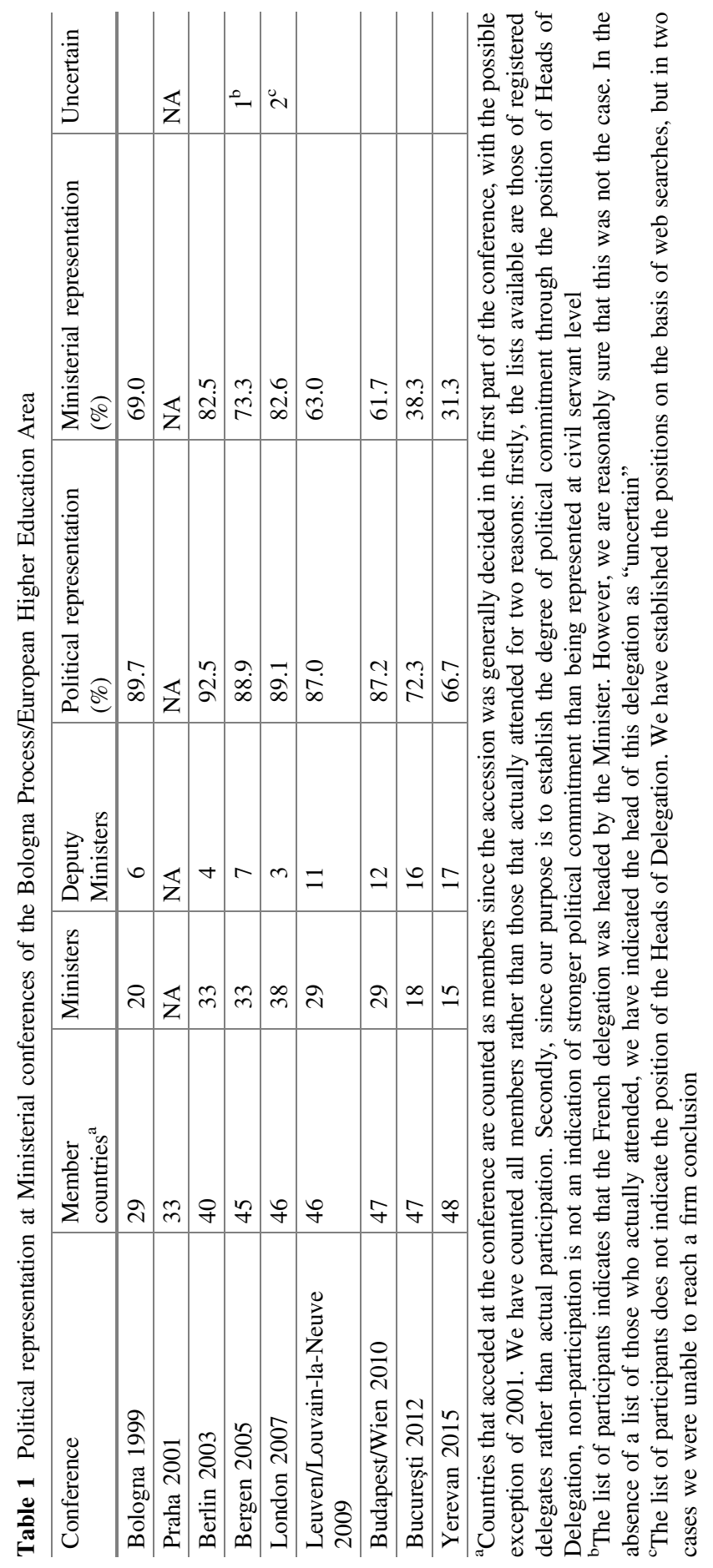


The feeling of loss of political relevance and also loss of a clear sense of direction was strengthened in the following period of the EHEA work program and in the preparation of the 2015 Ministerial conference in Yerevan. This was reflected in the inclusion of a session on the impact of the Bologna Process on the EHEA and beyond at the 2014 Bologna Researchers' Conference, ${ }^{10}$ for which two contributions in particular considered options for the future (Harmsen 2015; Bergan 2015). After some initial challenges, the drafting of the Yerevan Communiqué (Bologna Process 2015a) turned into a discussion that was largely focused on the further development of the EHEA. ${ }^{11}$ The drafters sought to give the Yerevan Communiqué a clearer focus and to identify challenges and policy measures rather than seek to provide an extensive overview of achievements and policy measures; an overview of policy measures adopted and commitments undertaken by Ministers in Yerevan will be found in the Appendix to the Communiqué. The Communiqué identifies four equally important goals as the Ministers" "collective ambition":

- Enhancing the quality and relevance of learning and teaching;

- Fostering the employability of graduates throughout their working lives in rapidly changing labor markets;

- Making our systems more inclusive;

- Implementing agreed structural reforms.

The Communiqué also makes it clear that "[t]he governance and working methods of the EHEA must develop to meet these challenges" (ibid.: 3).

The intensive work on the Communiqué, which involved several exchanges in the BFUG and the Board, was reflected in vivid discussions at the Yerevan Ministerial Conference itself. In our experience, which in one way or another spans all the Bologna Ministerial conferences since 1999, the discussions around the draft communiqué have never been as lively, and the number of amendments proposed and considered has never been as great, with the possible exception of the preparation of the Bologna Declaration. The evaluation report presented to the first BFUG meeting after the Yerevan Conference (Bologna Process 2015d), as well as informal feedback from delegations, also indicated they found the discussion stimulating and worthwhile.

\section{Running Out of Steam?}

The Yerevan Ministerial Conference therefore gave many participants a sense of optimism and achievement. The challenge would be to translate this renewed vigor into the new work program. In spite of the best efforts by the first BFUG Co-Chairs

\footnotetext{
${ }^{10}$ http://fohe-bprc.forhe.ro/2014/, accessed on November 19, 2017.

${ }^{11}$ The authors should again declare an interest: Sjur Bergan was one of the four main drafters of the Yerevan Communiqué.
} 
after the Ministerial conference-Liechtenstein and Luxembourg-and early meetings of both the Board and the BFUG, it soon became clear to many BFUG members that it would be difficult to maintain "the spirit of Yerevan". The vision displayed in the discussions of the Yerevan Communiqué was largely absent from those of the work program in the BFUG, ${ }^{12}$ and the focus was partly on organizational details. An attempt to reduce the number of thematic working groups led to three Working Groups - on Monitoring, Fostering implementation of agreed commitments, and Policy development of new EHEA goals-being supplemented by four Advisory Groups: International cooperation, Support for the Belarus Roadmap, Dealing with non-implementation, and Diploma Supplement revision. ${ }^{13}$

There were good reasons for establishing each and every working and advisory group, and these groups provide an opportunity to involve many representatives of countries and organizations to contribute to the implementation and development of the EHEA. It is, however, not evident that this potential has been realized. There may also be confusion about the remit of some of the groups in relation to other groups, in particular, those that have to do with monitoring, implementation, and non-implementation, even if the terms of reference per se do not overlap to a great extent.

Even more, however, some of the groups have faced considerable challenges in their work. They submitted their first reports to the BFUG in Tartu on November 9-10, ${ }^{14}$ shortly before the Bologna Researchers' Conference, and several of the groups will review their reports in the light of the discussion and submit their final reports in early 2018. It is therefore too early to pass definitive judgment. Feedback to the BFUG as well as informal feedback from the groups would, however, indicate that it would be challenging to reestablish the relative optimism that marked the Yerevan Conference and the run-up to it. The BFUG has had difficult discussions on the basis of preliminary reports by the Advisory Group on non-implementation that indicate considerable divergence in how the EHEA is viewed. The Advisory Group supporting the Roadmap accompanying Belarus' accession to the EHEA in 2015 faces difficulties in establishing the degree to which the Roadmap is being implemented, as well as in deciding what to recommend if it is not, even if some form of specific follow-up of higher education reforms in Belarus in the 2018-20 period seems likely. The Advisory Group on internationalization has struggled to devise a clear topic and format for the Bologna Policy Forum (BPF) and hence a clear rationale for holding it, even if a solution is now

\footnotetext{
${ }^{12}$ This is admittedly a subjective judgement but one based on participation in the discussions in both fora.

${ }^{13}$ For an overview, see http://www.ehea.info/pid35146/work-programme-2015-2018.html, accessed on November 2, 2017.

${ }^{14}$ http://www.ehea.info/cid115326/bfug-meeting-56.html, accessed on December 8, 2017.
} 
being devised. ${ }^{15}$ This is also due to the multiple views on what the BPF should represent, which vary according to the host country and to the predominant voices in the BFUG - a platform for policy exchange, a forum for agreeing on common cooperation goals with countries interested in the EHEA model, or a way to enhance inter-regional cooperation. Perhaps even more seriously, the Working Group on "new goals" seems to have faced serious difficulties in defining clear policy measures of interest to a majority of EHEA members and that lend themselves to the particular context of the EHEA.

\section{Challenges Beyond 2020}

From the relative optimism of Yerevan, the EHEA is therefore again faced with serious challenges that will determine its future orientation and perhaps even whether the EHEA will have a meaningful role beyond 2020. Without pretending to be exhaustive, we will seek to examine some of the main challenges.

\section{Reforming Education Systems}

The EHEA is an intergovernmental process. Its decision makers are the Ministers responsible for higher education of its 48 member states. This, of course, colors the process. Even if both international institutions and stakeholder organizations representing higher education institutions, students, staff, and employers are consultative members of the BFUG - and the European Commission even a full member -Ministers and their representatives make decisions, and they make decisions in areas that fall under their competence. Ministers are responsible for their countries' education systems (Bergan 2005, Council of Europe 2007). They are not directly responsible for the ways in which institutions teach, researchers work, students learn, or employers recruit, even if they may have a measure of political responsibility, and even if public authorities may take measures to encourage other actors to behave in certain ways. Vukasovic et al. (present volume) make a solid argument regarding how the complexity of EHEA governance can be better understood utilizing the "three multi-s" framework (multi-level, multi-actor and multi-issue).

It is therefore perhaps not surprising that the reform of education systems, and in particular of their structures, has been the hallmark of the Bologna Process and the EHEA. The three-tier degree system, qualifications frameworks, the recognition of qualifications, and quality assurance have been key topics either since the launch of

\footnotetext{
${ }^{15}$ The Bologna Policy Forum has been held in conjunction with every Ministerial Conference since 2009. It is intended to provide a platform for policy debate between EHEA Ministers and Ministers from other parts of the world with an interest in the development of the EHEA. In our judgement, the Forum has yet to find a convincing format, even if several options have been tested.
} 
the Bologna Process or shortly thereafter. ${ }^{16}$ The main standards, texts, and decisions of the EHEA concern structural reforms: the Overarching Framework of Qualifications of the EHEA (QF-EHEA $)^{17}$ as well as the standards and guidelines for quality assurance in the European Higher Education Area (ESG) ${ }^{18}$ were adopted by the Bergen Ministerial Conference (Bologna Process 2005). The Lisbon Recognition Convention (Council of Europe/UNESCO 1997) was included already in the Sorbonne Declaration (Bologna Process 1998), followed by later calls to ratify it (e.g. Bologna Process 2005), something that has now been done by all EHEA members, except Greece. ${ }^{19}$ The Diploma Supplement and the European Credit Transfer and Accumulation System (ECTS) have also been the subject of Ministerial attention and commitments (e.g. Bologna Process 2003). Structural reforms have also been the topic of several working groups, including one that reviewed the full range of structural reforms (Bologna Process 2014).

Structural reforms lend themselves to the loose organization of the EHEA, in which overall policies are decided by Ministers at European level and implemented nationally and within higher education institutions. As an example, the QF-EHEA sets the frame or "outer limits" within which countries develop their national qualifications frameworks. They have considerable leeway in doing so, as demonstrated by the fact that in some countries the first degree assumes a workload of 180 ECTS credits and in others up to 240. There are, nevertheless, limits to national discretion: no country could develop a framework in which the first degree would require, for example, 360 ECTS credits and make a credible claim to compatibility with the QF-EHEA.

The succession of stocktaking and monitoring reports ${ }^{20}$ show, however, that implementation is uneven and that some countries are far from fulfilling their commitments in one or more areas of structural reforms. Other countries are even tempted to go back on some of the implemented reforms, in particular, the three cycle degree system. This diminishes the credibility of the EHEA as a framework within which national qualifications are compatible, are issued within comparable qualifications structures, are quality assured according to agreed standards and guidelines and are described in easily understandable formats. It is worth noting that

\footnotetext{
${ }^{16}$ The Bologna Declaration refers to a two-tier degree system; the third tier, doctoral qualifications, as well as a reference to qualifications frameworks were first included in the Berlin Communiqué (Bologna Process 2003). Quality assurance was firmly established as a "Bologna topic" through the Prague Communiqué (Bologna Process 2001).

${ }^{17} \mathrm{See}$ http://www.ehea.info/pid34779/qualifications-frameworks-three-cycle-system-2007-2009. html, accessed on November 2, 2017.

${ }^{18}$ The ESG were revised by Ministers in Yerevan (Bologna Process 2015a). The current version will be found at https://media.ehea.info/file/2015_Yerevan/72/7/European_Standards_and_ Guidelines_for_Quality_Assurance_in_the_EHEA_2015_MC_613727.pdf, accessed on November 2, 2017.

${ }^{19}$ An updated overview of signatures and ratifications will be found at http://www.coe.int/en/web/ conventions/full-list/-/conventions/treaty/165/signatures, accessed on November 2, 2017.

${ }^{20}$ For an overview, see http://www.ehea.info/pid34367/implementation-and-national-reports.html, accessed on November 2, 2017.
} 
the seemingly straightforward commitment of issuing the Diploma Supplement automatically, free of charge and in a widely spoken language by 2005 , undertaken in Berlin (Bologna Process 2003) was only partly fulfilled 10 years later (European Commission/EACEA/Eurydice 2015: 74-76).

The relative lack of implementation of some structural reforms led to the setting-up of the Advisory Group on non-implementation in the 2015-18 EHEA work program, as discussed by Strand Viðarsdóttir in this volume. As non-implementation has to do with the broader discussion of the governance of the EHEA, it will be considered below. Dang (present volume) offers an interesting comparison of challenges of implementation in the contexts of the EHEA and the ASEAN Common Space for Higher Education and introduces the concept of "façade conformity".

\section{Teaching and Learning}

Teaching and learning are, together with research, at the core of higher education, and even more so in the EHEA which has not focused extensively on research policy beyond issues related to doctoral education. At the same time, teaching and learning are not primarily Ministry activities. Ministries may learn, of course, but teaching and learning are done by teachers and students at higher education institutions, albeit within an overall framework established by public authorities.

The culture and style of teaching vary very considerably between countries, institutions, and even individual teachers and students throughout the EHEA. Some see teaching as a one-way communication — or perhaps rather transmission-from teachers to students, whereas others emphasize interaction. Auditorium lectures are often supplemented by seminar groups, discussion groups, tutoring, or other forms of more interactive teaching, but sometimes one-way communication from teachers to students is predominant. The concept of student centered learning is by now firmly established in the EHEA starting with the Leuven/Louvain-la-Neuve Communiqué (Bologna Process 2009: 3) and has been the subject of studies European Students' Union (2015) and projects (T4SCL ${ }^{21}$ and EFFECT ${ }^{22}$ ). Student centered learning emphasizes, among other things, innovative teaching methods, digital technologies, and pedagogical innovation. In many institutions, these goals are still aspirational at best. Nevertheless, the fact that student centered learning is

\footnotetext{
${ }^{21}$ https://www.esu-online.org/?project=time-student-centred-learning, accessed on November 2, 2017.

${ }^{22} \mathrm{https}$ ://www.esu-online.org/?project=european-forum-enhanced-collaboration-teaching-effect, accessed on November 2, 2017.
} 
now among the topics warranting a separate sub-site within the EHEA website ${ }^{23}$ gives hope that teaching and learning will evolve considerably throughout the EHEA.

Self-study and the ability to search and assess information are also an important part of higher education learning. Classical libraries, which incidentally suffer from the high price of many academic publications and journals at a time when higher education institutions feel the impact of economic constraints, are supplemented by other sources of information, notably web-based (and often open source). With the almost explosive increase in the information available, developing the ability to identify and assess information is becoming even more critical.

One of the main challenges in teaching and learning will be to blend and make good use of the many different methods and modes of delivery that are available now and will continue to develop over the coming years. It is our assertion that no single mode will be adequate to provide quality teaching and learning. Rather, any teaching method, to be effective, will need to be used in combination with other methods. Digitalized and web based education is set to change teaching and learning in ways we can still not foresee, but it is our assertion that they will not be able to replace face to face teaching and learning in all circumstances and for all purposes. MOOCs will remain but they are unlikely to reign uncontested. Universities will need to change profoundly to benefit from new technologies and methods as well as to avoid their pitfalls, but if they do, the announcement of the "death of the university" will not only have been premature but a false alarm. On the contrary, we believe that one of the hallmarks of high quality institutions in the future will be their ability to use the full range of teaching and learning methods, from auditorium lectures through face to face interaction between teachers and students as well as among students to digital learning and teaching.

It would make sense for the European Higher Education Area to make teaching and learning the focus of its further development, as outlined in the final reports of the 2nd edition of the Bologna Process Researchers' Conference. ${ }^{24}$

\section{Technical Reforms or Commitment to Fundamental Values?}

Structural reforms have been the most successful policy area of the EHEA. Even if implementation is uneven, the EHEA has developed standards for qualifications frameworks and quality assurance, established a European Quality Assurance Register for higher education (EQAR), ${ }^{25}$ adopted the principle of a three-tier degree

\footnotetext{
${ }^{23}$ See http://www.ehea.info/pid34437/student-centred-learning.html, accessed on November 2, 2017.

${ }^{24}$ https://media.ehea.info/file/2015_Yerevan/73/5/06052015_FOHE-BPRC2_Final_report_ 613735.pdf, page 8, accessed on November 2, 2017.

${ }^{25}$ https://www.eqar.eu/, accessed on November 2, 2017.
} 
system, incorporated the Lisbon Recognition Convention as the basis for the recognition of qualifications, and made good use of the Diploma Supplement and the ECTS as transparency instruments, even to the extent of establishing an Advisory Group to review the former and adopting the revised ECTS User's Guide as an official EHEA document (Bologna Process 2015a: 4).

In spite of the uneven implementation of structural reforms throughout the EHEA, we would therefore argue that the EHEA has been successful in devising and reasonably successful in implementing reforms of education systems. We would equally argue that Ministers and the BFUG have been less good in outlining and explaining the main principles behind these reforms as well as the values on which the EHEA builds.

A consideration of values has certainly not been absent from the EHEA. The Bologna Declaration refers to the "importance of education and educational co-operation in the development and strengthening of stable, peaceful and democratic societies" (Bologna Process 1999: 1) as well as "the fundamental principles laid down in the Bologna Magna Charta Universitatum of 1988" (ibid.: 2). The latest communiqué refers to "public responsibility for higher education, academic freedom, institutional autonomy, and commitment to integrity" (Bologna Process 2015a: 1) and includes, as we have seen, making education systems more inclusive among the four priorities defined for the 2015-18 work program. In this context, Ministers state: "We will enhance the social dimension of higher education, improve gender balance and widen opportunities for access and completion, including international mobility, for students from disadvantaged backgrounds. We will provide mobility opportunities for students and staff from conflict areas, while working to make it possible for them to return home once conditions allow" (ibid.: 2-3). The Roadmap accompanying Belarus' accession to the EHEA, also adopted by Ministers in Yerevan, includes the fundamental values of the EHEA as one of the areas in which Belarus needs to demonstrate adherence to adopted EHEA principles and policies, with reference to the Yerevan Communiqué, the Magna Charta Universitatum, ${ }^{26}$ and Council of Europe recommendation Rec/CM(2012)7 on the public responsibility for academic freedom and institutional autonomy ${ }^{27}$ (Bologna Process 2015b: 2-3).

Nevertheless, it seems fair to say that the fundamental values on which the EHEA builds - in particular academic freedom, institutional autonomy, student participation in higher education governance, and public responsibility for higher education (Bologna Process 2004) - have not received the attention they would deserve in the BFUG or in public EHEA statements and policies. The reasons for this are of course not stated, but it seems safe to surmise that at least two factors have played a considerable role.

\footnotetext{
${ }^{26}$ Available at http://www.magna-charta.org/magna-charta-universitatum, accessed on November 2, 2017.

${ }^{27}$ Available at https://search.coe.int/cm/Pages/result_details.aspx?ObjectId=09000016805ca6f8, accessed on November 2, 2017.
} 
The EHEA is a political process with regular milestones in the form of Ministerial conferences held every two or three years. Ministers reasonably wish to demonstrate commitment to clear goals as well as progress in achieving these goals. Qualifications frameworks and quality assurance standards lend themselves to such a schedule: they can be adopted by Ministers and progress in implementation can be measured. Ministers can "tick the box" as far as their countries are concerned when the stated goals have been met. The fundamental values are less easily measured and their implementation perhaps more prone to fluctuate with shifting governments and political circumstances. In this case, the EHEA may be seen as giving importance to what can be measured, rather than measuring everything that is important - but this statement should of course not be taken to imply that structural reforms are unimportant.

More importantly, the fundamental values are closely linked to the overall situation of democracy and human rights in EHEA countries, and the EHEA is not an area of democratic perfection. Several members have issues with democracy and human rights. Not only are these highly sensitive issues where few countries would admit to fundamental problems but they are generally considered as pertaining to the domain of Ministries of Foreign Affairs or even Heads of State or Government. Facing challenges in implementing one's national qualifications framework is one thing, and the responsibility lies squarely with the public authority responsible for education. Facing challenges in implementing democracy and human rights is quite another story, and it is not one that primarily falls within the remit of the Minister of Education. Formally, regulations concerning student participation in higher education governance or institutional autonomy do, but no Minister of Education can promote democratic governance of universities if democratic governance faces serious challenges overall in the country.

It is politically difficult for governments to advocate measures against other governments for breach of fundamental EHEA principles. Such measures are likely to be taken only in extreme cases. An important consideration is also whether one is more effective in assisting those who work for higher education reform and/or democracy by engaging with a country or by keeping it out of the EHEA. Most would agree that at some point the balance between engagement and a clear public statement of fundamental principles will tip but the point is not easy to identify, and agreement on where it may be located has proved elusive.

The partial exception has been Belarus, where an interest in accession was rejected twice for political reasons. In the run-up to the Bergen conference in 2005, it was communicated unofficially to Belarus that a formal accession application was very likely to be rejected, ${ }^{28}$ and the authorities chose not to apply. In the run-up to the Bucharest conference, Belarus did submit a formal application that was given due consideration by the BFUG. However, the arrests of faculty members and students during the widespread protests against the presidential election in

\footnotetext{
${ }^{28} \mathrm{By}$ the nature of things, documentation of this is difficult to produce, but one of us (Sjur Bergan) was involved in the discussions.
} 
December 2010, which was widely perceived as unfair, ${ }^{29}$ made it impossible for the BFUG to recommend to Ministers that they welcome Belarus as an EHEA member (Bologna Process 2012b: 24-25). When Belarus was admitted in 2015, these discussions were part of the reason why the accession was accompanied by a Roadmap (Bologna Process 2012b), in addition to the fact that Belarus was the first country to accede after the formal establishment of the EHEA in 2010.

Recently, the BFUG has again placed academic freedom and institutional autonomy on its agenda, through a thematic debate at its meeting in Bratislava in December 2016 (Bergan et al. 2016). The purpose of the discussion was to discern issues of principles and to arrive at a more nuanced view of academic freedom and institutional autonomy than the one that simply views them in terms of the legal relationship between public authorities (often referred to as "the State") and the academic community. Even though several EHEA countries can reasonably be considered to be in breach of one or more fundamental principles, the debate did not aim to identify specific cases, and EHEA members have been reluctant to do so. In the immediate aftermath of the failed coup in Turkey in July 2015, when members of the academic community were barred from traveling abroad on business and deans at all Turkish universities were temporarily suspended, several EHEA members informally questioned Turkey's status within the EHEA. ${ }^{30}$ However, these countries later softened their stance, partly because some of the measures were eased - even if many members of the academic community were still hit by measures - and partly because most European countries found it more fruitful to work within Turkey to try to help nudge developments in the direction of greater democracy or at least avoiding the worst excesses rather than seek to isolate the country. Higher education policy was therefore aligned with foreign policy, despite being in a situation similar to the Belarus accession application in 2012.

The BFUG has so far not addressed the changes to the Hungarian higher education law that put the viability of the Central European University as a Budapest-based institution in doubt. It will be interesting to see how the BFUG and then Ministers would handle this sensitive issue if the crisis persists. Matei and Iwinska (present volume) introduce the notion that institutional autonomy has gained a European conceptual understanding, while academic freedom benefitted from less attention in the EHEA discussions. The Hungarian situation is presented as a clear example of how these two basic EHEA values - institutional autonomy and academic freedom - are dependent on each other, but should not be considered as intrinsically linked.

\footnotetext{
${ }^{29}$ See for example the joint statement by the Foreign Ministers of the Czech Republic, Germany, Poland, and Sweden published in the New York Times on December 23, 2010, available at http:// www.nytimes.com/2010/12/24/opinion/24iht-edbildt24.html?_r=1\&scp=2\&sq=Carl\% 20Bildt\&st=cse, accessed on November 2, 2017.

${ }^{30}$ Personal communications that for obvious reasons will remain anonymous. Some higher education NGOs, including the European Students' Union and the European University Association, did issue critical statements.
} 
More broadly, as discussed by Tony Gallagher in this volume, the civic and democratic role of higher education could and should be one of the main challenges of the EHEA. Higher education has an important role in developing the democratic culture without which democratic laws and democratic institutions will not function. $^{31}$

\section{Commitments and Governance}

The difficulties governments face in criticizing other governments over issues with fundamental values have also been found in other and a priori less controversial policy areas. Through the Bologna Declaration and successive Ministerial communiqués, EHEA members have committed to principles and policies that need to be implemented in each country. The stocktaking and monitoring reports show that successful implementation is less than universal, which leads to the question of how to address non-implementation.

This is not a new issue in the Bologna Process. As 2010 and the formal establishment of the EHEA approached, there was discussion of how the transition from the Bologna Process to the EHEA could best be organized and of whether any member of the Bologna Process would automatically become a member of the EHEA, regardless of the country's record in implementing key policies and priorities. The option of establishing the EHEA through an international convention to which countries would accede and that would outline their obligations as well as mechanisms for addressing non-implementation was raised and discarded in the run-up to the Bergen conference in 2005. ${ }^{32}$ The discussions in the BFUG in the mid- to late 2000's are well summarized in an excerpt from the minutes of the BFUG meeting in October 2006:

There was a need to consider how the transition from the Bologna Process to the European Higher Education Area could best be made. This would include deciding how to react if stocktaking for 2010 showed that a number of countries had yet to implement or achieve key goals of the Process. Options could range from deciding that all countries of the Bologna Process would automatically become members of the EHEA; deciding that all countries would become members but that assistance would be offered to those that had not yet achieved all the key goals; or deciding that only those who had achieved the key goals could become members of the EHEA in the first instance. It would be important to consider the range of possible options prior to 2010 .

There was widespread recognition that current informal, flexible approach had served the Process very well. (Bologna Process 2006: 11).

\footnotetext{
${ }^{31}$ Several volumes in the Council of Europe Higher Education Series explore the democratic mission of higher education. See e.g. Klemenčič et al. (2015), Bergan et al. (2015), Bergan et al. (2014), and Bergan (2011).

${ }^{32}$ Personal recollection (Sjur Bergan).
} 
The discussion on how to address non-implementation has always been difficult, and it has never completely disappeared, but it resurfaced more explicitly through the Yerevan Communiqué. Ministers ask the BFUG "to review and simplify its governance and working methods, to involve higher education practitioners in its work programme" and at the same time "to submit proposals for addressing the issue of non-implementation of key commitments in time for our next meeting" (Bologna Process 2015a: 3).

Some researchers also pointed to a more legally binding format for the EHEA commitments as a possible way to enhance accountability and bring the Bologna Process closer to EU instruments (see Garben 2011).

The Yerevan Communiqué thus links governance and non-implementation. The view we take of whether and how non-implementation need to be addressed is linked to how the EHEA is viewed. In one view (see e.g. Harmsen 2015), the EHEA is essentially an area of peer learning, where countries develop good practice by learning from each other but where it is either not desirable or not possible —or neither desirable nor possible - to take measures to address cases where countries do not implement commitments. Another view (see e.g. Bergan 2015) recognizes the importance of peer learning in developing the EHEA but emphasizes that to be credible as an area in which qualifications are broadly and automatically recognized based on qualification frameworks and standards for quality assurance as well as commitment to common fundamental values, the EHEA needs a mechanism for addressing serious cases of non-compliance.

To meet the Ministers' request, the BFUG appointed an Advisory Group on non-implementation in the 2015-18 work program, co-chaired by Iceland and Liechtenstein. Its remit is to "submit proposals for addressing the issue of non-implementation and incorrect implementation of key commitments (how to implement them best by respecting and reflecting the EHEA instruments and the EHEA culture)" (Bologna Process 2015c: 1). Preliminary reports from this Advisory Group were the subject of difficult discussions in the BFUG in December 2016 and May 2017 when the group put forward proposals for a system of cyclic reviews of key commitments, in the first instance linked to structural reforms. Under this model, the BFUG Co-Chairs would initiate dialogue with and offer assistance to EHEA members for which the previous monitoring report would demonstrate serious concerns about implementation. Countries themselves could also request advice and assistance. On both occasions, a clear majority of delegations that took the floor spoke in favor of the proposal by the Advisory Group, but a minority of delegations were outspoken proponents of the view that the EHEA should be an area of peer learning without any "constraints" on members. The further discussions at the BFUG meetings in Tartu in November 2017 and Sofia in February 2018 confirmed this orientation, and the Advisory Group has now submitted a revised proposal that moves quite far in the direction of countries requesting peer learning if they themselves feel they have issues with implementation. There is no longer a reference to the possibility of the BFUG Co-Chairs or a BFUG-appointed body approaching countries to suggest that in view of their score in the implementation report, they may benefit from cooperation in implementing 
specific commitments. In our view, these developments weaken the view that that while membership of the EHEA is voluntary, implementing the commitments members undertake on joining is not. Reference is again made to Strand Viðarsdóttir's article in this volume.

At the time of writing, the debate on non-implementation overshadows other issues of governance. There is nevertheless concern that BFUG delegations carry insufficient political weight in their own Ministries and are therefore not always able to speak on behalf of their authorities. This is clearly not the case of all delegations, but the concern is serious enough to be raised from time to time, at least informally. There has been no substantial discussion of voting arrangements, and one application from an NGO for observer status was turned down. Despite this situation, a substantial change in the governance structures seems unlikely in the near future, as it would have to be agreed by the same delegations that are considered to have less political weight than the process would need.

A change in Secretariat arrangements also seems unlikely. At present, the country hosting the upcoming Ministerial conference also provides the Bologna Secretariat. The Secretariats have typically been staffed by nationals of the same country $^{33}$ and have operated under the laws of this country. France, while providing the Secretariat under French law and within French structures for the 2015-18 period, has associated some non-French experts with the Secretariat, as well as one full-time staff member provided by Germany. Many BFUG members have expressed a desire for a more international Secretariat with a longer mandate than from one Ministerial conference until the next. This model has often been labeled a "permanent Secretariat". The practical, financial, and legal issues ${ }^{34}$ involved in establishing a Secretariat that would de facto be a new international NGO serving an intergovernmental process are, however, so complex that the BFUG decided not to pursue this option further, at least in the current period (Bologna Process 2017: 7-8). Secretariat arrangements may become a part of the discussion on the EHEA beyond 2020 leading up to the 2020 Ministerial conference, but the challenges in identifying alternative arrangements will remain formidable, especially in light of the previous attempt to establish a more permanent Secretariat structure (put forward by the Parliamentary Assembly of the Council of Europe (PACE 2009); it should be noted that the latter did not have the support of the Council of Europe Secretariat or the Council's (then) Steering Committee on Higher Education and Research).

\footnotetext{
${ }^{33}$ With the exception of the period 2007-10, when Belgium, Luxembourg and the Netherlands were joint hosts of the Louvain-la-Neuve conference and provided a joint Secretariat, which continued to operate through the 2010 Ministerial conference in Budapest and Wien, reinforced by one Austrian and one Hungarian staff member.

${ }^{34}$ For a somewhat more detailed consideration, see Bergan 2015: 746-748.
} 


\section{Two Speeds or Development Adapted to Local Circumstances?}

The challenges in implementing policies and commitments undertaken through the Bologna Declaration and communiqués could be read as indicating an uneven commitment to the EHEA. To an extent, this is undoubtedly true, and even within countries, different governments have demonstrated different levels of enthusiasm in implementing "Bologna reforms". One example among several is Georgia which was well engaged in reforms up until around 2007 or 2008. A period of relative inactivity both in the BFUG and in internal reforms then followed, but Georgia has again been an active contributor to the BFUG and also launched national reforms since around 2013.

Uneven implementation is not solely a question of a north/south or east/west divide or a divide between countries that joined the Bologna Process in the early years and those that joined later and therefore had less time to implement the reforms since the expectation was-at least officially - that all EHEA members would have met the same goals by 2010 .

At the same time, not only have countries joined the EHEA at different times, they have also had different starting points when doing so. The Bologna Process was launched less than 10 years after the fall of the Berlin Wall, a symbolic but very real moment that more broadly indicates regime change in many European countries. As a result of these changes, the membership of the Council of Europe doubled between 1989 and today, the Bologna Declaration was signed by Ministers from 29 countries, including several that had been part of the Warsaw Pact and three that had even been part of the Soviet Union. Academic mobility was extended to all parts of Europe on a much larger scale and with fewer restrictions that had previously been imaginable.

Even if the EHEA looks toward the future in setting goals for common principles and policies, national education systems are also inheritors of the past. Europe can be seen as a unique balance of what we have in common and what is specific to individual countries, cultures, or regions. Six EHEA members shared the education system and traditions of former Yugoslavia until the early 1990s. Even if Bosnia and Herzegovina, Croatia, Montenegro, Serbia, Slovenia and "the former Yugoslav Republic of Macedonia" have developed their education systems at different speeds and partly in different directions, and even if the break-up of former Yugoslavia had a different impact on each of the countries, they share a recent past that in some aspects sets them apart from the experience of other EHEA members. The same is true for countries that were a part of the former Soviet Union, where the differences in the development trajectories after independence are greater but a shared past nevertheless colors the present to some extent.

The weight of the past is of course not specific to countries that have undergone dramatic upheavals over the past generation. To some extent, all EHEA members are marked by their past. Some differences that come to mind include centralized 
versus decentralized systems, the differences between larger and smaller systems, and the degree to which systems differentiate between different kinds and profiles of higher education institutions (Deca 2016). Armağan Erdoğan describes developments and prospects in the case of Turkey (Erdoğan 2015).

One of the challenges in the further development of the EHEA will therefore be to reconcile the need to ensure implementation of common principles and goals with the need to recognize that EHEA members have different traditions as well as recent pasts. Different traditions may offer an explanation of why certain reforms are particularly challenging or why they may take a long time to implement, but they should not provide reasons why EHEA would not see a need to launch the reforms they have committed to when joining the Bologna Process.

\section{An EHEA Gazing Inward or Looking Out?}

The EHEA has been followed with great interest in other parts of the world. Examples include academic publishing in the United States (Adelman 2009; Gaston 2010), as well as policy initiatives in Asia (Dang 2015 and in the present volume). The development of qualifications frameworks was not a European invention, with Australia, New Zealand, and South Africa as pioneers, but the current interest in qualifications framework would most likely not have come about without the decision by EHEA Ministers to adopt an overarching framework and to develop national frameworks compatible with the QF-EHEA. To our knowledge, the notion of a regional qualifications framework was pioneered by the EHEA. Later, the European Training Foundation has played an important role in promoting the development of qualifications frameworks in different parts of the world and for all levels and strands of education.

In spite of the strong interest in the EHEA from countries outside of Europe, and in spite of the equally strong interest among many EHEA members in developing global or at least inter-regional dialogue and cooperation on higher education reform, attempts to do so in the framework of the EHEA have so far been unsuccessful. The EHEA interest was manifested through a report on the "Bologna Process in a global setting" as early as 2007 (Zgaga 2007), as well as the adoption of a "global dimension" strategy (Bologna Process 2007b).

The first Bologna Policy Forum was held in 2009, a forum for exchange and debate at political level between EHEA Ministers and Ministers from selected countries in other parts of the world. Since then, the Policy Forum has been held in conjunction with every Ministerial conference, but it has proven difficult to move beyond relatively superficial discussions or to maintain political interest. Different formats have been tried, ranging from plenary debates to thematic discussion groups within the Forum, and with targets ranging from all regions of the world to a modified format with a stronger regional focus in 2015. 
The reasons for this lack of success have not been fully explored, but it seems reasonable to assume that they may have to do with the format of the Forum as well as the lack of follow up between high level meetings with a political focus. Including a half day or one day session with non-EHEA ministers in the regular EHEA Ministerial meetings is unsatisfactory to the non-EHEA Ministers who would need to travel long distances for a short conference. At the same time, BFUG delegations have expressed strong and consistent concerns that their Ministers would not be prepared to add a day and a half or two days to the Ministerial conference. There has also so far been no effective follow-up work under the auspices of the BFUG in the periods between Ministerial conferences and Bologna Policy Forum, so that there have been no Policy Forum dialogues with regions outside of Europe on EHEA topics like structural reforms, the social dimension of higher education, or fundamental values like academic freedom and institutional autonomy. This may at least in part be due to the fact that there is no specific budget for the EHEA beyond what each member invests in its own participation and activities and the host country invests in the Secretariat. One consequence of this is also that non-EHEA countries play a very limited role in preparing the Bologna Policy Fora and could understandably see them as an invitation to dialogue with agendas set entirely by the EHEA.

The fact that the specific EHEA attempts to establish a forum for cooperation have largely failed does not mean there is little cooperation between European actors and public authorities and higher education communities outside of Europe. The European Commission, NGOs like the International Association of Universities, the European University Association, and the European Students' Union as well as individual countries are engaged in extensive cooperation and much of it focuses on policy areas inspired by the EHEA. A particularly interesting example is the Asia-Europe cooperation, as described by Dang (2015, 2017). This cooperation includes regular meetings of higher education leaders as well as of Ministers, and attendance at the Ministerial meetings tends to surpass political level participation at the Bologna Policy Fora. A comparative study of the involvement of relatively peripheral countries in the EHEA and the ASEAN Common Space for Higher Education will be found in QueAnh Dang's contribution to the present volume.

Challenges in the further development of the EHEA include finding an attractive format for organized cooperation between the EHEA and other parts of the world, through the BFUG and not only through individual actors, as well as defining attractive priorities for that cooperation. However, the challenges also relate to the internal development of the EHEA: will the EHEA develop in ways that will make it credible as a higher education area and not just as an area of more or less organized peer learning? An EHEA that were only to gaze inward would be neither an attractive cooperation partner nor a model for emulation, but neither would an EHEA that were unable to identify credible goals, ensure credible implementation, or develop credible governance. 


\section{Professional Higher Education}

Even if preparation for the labor market is an important purpose of higher education in all 48 EHEA members, their traditions vary greatly. In particular, the extent to which the traditional university is supplemented by institutions and programs providing shorter and more specifically employment oriented qualifications varies considerably. The proposed QF-EHEA as submitted to the Ministers in Bergen in 2005 included provision for short cycle qualifications within the first cycle. This was, however, rejected by the Ministers, who could accept this only as an option within national frameworks, but not as a feature of the QF-EHEA (Bologna Process 2005: 2). In part, Ministers found it difficult to accept that the QF-EHEA might include a qualification they did not intend to develop in their own country. In part, some Ministers seem to have found it difficult to accept short cycle qualifications as higher education. In the debate, one Minister, who shall remain unidentified, even maintained that nothing short of three years could be considered higher education. ${ }^{35}$

\section{Demographics}

The influence of demographic developments on the number of students and, more broadly, on the development of higher education, has been curiously absent from discussion on the development of the EHEA. Roderick Floud's statement to the London Ministerial Conference to the effect that "I did not hear a single reference in either the plenary sessions or in the panel discussions, to demography, either of our populations in general or in relation to higher education staff and students. Yet the challenges here for us are immense" (Bologna Process 2007c: 9) remains valid today.

In the present volume, Robert Santa illustrates the importance of demographic developments to higher education through a case study of Poland, Russia, and Romania.

\section{The EHEA: A Framework Fit for Purpose?}

The EHEA was devised to address a set of issues of concern to European Ministers in the late 1990s. The challenges had to do with the extent to which European higher education was seen as credible and attractive to European actors like students, employers and policymakers as well as to actors - not least students-from other parts of the world. They also had to do with the extent to which students in Europe completed their studies with success and within reasonable time as well as the extent to which European study programs were seen as "fit for purpose".

\footnotetext{
${ }^{35}$ Personal recollection.
} 
To a large extent, the response to the challenge lay in reforming education structures and systems. But the originality of the Bologna Process was perhaps less to be found in the topics chosen than in the proposition that the challenges could be met only through European cooperation, as well as in the proposition that an intergovernmental process needed to include higher education institutions, students, faculty, international institutions and other stakeholders to be successful.

In our view, the EHEA has been successful, in spite of the criticism contained in these pages. Its success is demonstrated by the fact that it is exceedingly difficult to imagine what higher education in Europe would have been like today had there not been a broad, if fairly loosely organized, cooperation that included not only public authorities but also higher education stakeholders and civil society, and had that process not been flexible enough to admit new members. The fact that it has grown from the original 29 countries to the 48 EHEA members of today is also a witness to its success. The EHEA is not a forum from which many European countries feel they can afford to remain aloof.

The EHEA was a structure and a cooperation fit for the challenges facing Education Ministers and the higher education community some 20 years ago. An important part of the challenge to "the future of Bologna" is to identify challenges that are of political importance and that can be addressed within the loose and extensive structure that is the EHEA. Or failing that, to redefine those structures so that a different EHEA can meet new challenges.

The rather optimistic assertion in the BFUG discussion paper on "Bologna 2020" to the effect that "it is, therefore, necessary that the Bologna Process should continue after 2010 so that its implementation can be finalized" (Bologna Process 2008: 3 ) is therefore still valid if one substitutes 2010 for 2020 . We fear it will be valid even longer.

That, however, is positive. The assertion raises the question of whether the implementation of the Bologna Process can be meaningfully "finalized". It may be akin to our private definition of lifelong learning as the kind of learning about which nobody can speak from the point of view of a fully accomplished learner since by definition a fully accomplished lifelong learner is no longer alive.

The European Higher Education Area faces formidable challenges in staying relevant and in improving the daily lives of students and staff. It is our belief that in spite of the difficulties, these challenges can be met provided there is both political and practical will to do so, and that includes the will and ability to finance the endeavor.

A European Higher Education Area that considered itself "fully implemented", on the other hand, would not only be increasingly irrelevant. It would be dead.

\section{References}

Adelman, C. (2009). The Bologna process for U.S. eyes: Re-learning higher education in the age of convergence. Washington, D.C.: institute for Higher Education Policy.

Bergan, S. (2005). Higher education as a "Public Good and a Public Responsibility": What does it mean? In L. Weber \& S. Bergan (Eds.), He public responsibility for higher education and 
research (pp. 13-28). Strasbourg: Council of Europe Publishing-Council of Europe Higher Education Series No. 2.

Bergan, S. (2011). Not by bread alone. Strasbourg: Council of Europe Publishing. Council of Europe Higher Education Series No. 17.

Bergan, S. (2015). The EHEA at the Cross-roads. The Bologna Process and the Future of Higher Education. In A. Curaj, L. Matei, R. Pricopie, J. Salmi, \& P. Scott (Eds.), The European Higher Education Area: Between critical reflections and future policies (pp. 737-752). Heidelberg: Springer Open Access.

Bergan, S., Egron-Polak, E., Noorda, S., \& Pol, P. (2016). Academic freedom and institutional autonomy-What role for the EHEA? Background document for the thematic session at the meeting of the Bologna Follow-Up Group, Bratislava, December 8-9, 2016. Retrieved from https://media.ehea.info/file/20161208-09-Bratislava/12/8/BFUG_SK_ME_52_9_ Fundamental_values_669128.pdf. Accessed November 2, 2017.

Bergan, S., Gallagher, T., \& Harkavy, I. (Eds.). (2015). Higher education for democratic innovation. Strasbourg: Council of Europe Publishing. Council of Europe Higher Education Series No. 21.

Bergan, S., Harkavy, I., \& van't Land, H. (Eds.). (2014). Reimagining democratic societies: A new era of personal and social responsibility. Strasbourg: Council of Europe Publishing. Council of Europe Higher Education Series No. 18.

Bologna Process. (1998). Sorbonne Joint Declaration. Joint declaration on harmonisation of the architecture of the European higher education system by the four Ministers in charge for France, Germany, Italy and the United Kingdom. Paris, The Sorbonne, May 251998.

Bologna Process. (1999). The Bologna Declaration of 19 June 1999. Joint declaration of the European Ministers of Education.

Bologna Process. (2001). Towards the European Higher Education Area. Communiqué of the meeting of European Ministers in charge of Higher Education in Prague.

Bologna Process. (2003). Realising the European Higher Education Area. Communique of the Conference of Ministers responsible for Higher Education in Berlin on 19 September 2003.

Bologna Process (2004). Further accession to the Bologna process. Procedures for Evaluation of Applications and Reports from Potential New Members" Document BFUG B3 7 dated October 4, 2004. Retrieved from https://media.ehea.info/file/20041012-13_Noordwijk/79/9/BFUG3_7_ further_accessions_579799.pdf, on November 2, 2017.

Bologna Process. (2005). The European Higher Education Area-Achieving the goals. Communique of the Conference of European Ministers Responsible for Higher Education, Bergen, 19-20 May 2005.

Bologna Process. (2006). Meeting of the Bologna Follow-Up group, Helsinki, Finland, 12-13 October 2006, document BFUG10 3a. Retrieved from https://media.ehea.info/file/2006101213_Helsinki/04/5/BFUG9_Minutes_Helsinki_October2006_585045.pdf.

Bologna Process. (2007a). London Communiqué. Towards the European Higher Education Area: Responding to challenges in a globalised world. Retrieved from https://media.ehea.info/file/ 2007_London/35/4/2007_London_Strategy-for-EHEA-in-global-setting_581354.pdf, on November 2, 2017.

Bologna Process. (2007b). European higher education in a global setting. A strategy for the external dimension of the Bologna process. Retrieved November 2, $2017 \mathrm{https} / / /$ media.ehea. info/file/2007_London/35/4/2007_London_Strategy-for-EHEA-in-global-setting_581354.pdf.

Bologna Process. (2007c). Bologna Ministerial Conference: London 17-18 May 2007 feedback from panel sessions. Retrieved from https://media.ehea.info/file/2007_London/89/6/2007_ LondonMinisterialConference_PanelSessionOutcome_588896.pdf, on November 2, 2017.

Bologna Process. (2008). "Bologna 2020”. Discussion document issued to the Bologna Follow Up Group for its extraordinary meeting in Sarajevo, issue date June 12, 2008. Retrieved from https://media.ehea.info/file/20080624-25-Sarajevo/01/1/BFUG_Sarajevo_Bologna2020paper_ 593011.pdf, on November 2, 2017. 
Bologna Process. (2009). "The Bologna Process 2020 - The European Higher Education Area in the new decade" Communiqué of the Conference of European Ministers Responsible for Higher Education, Leuven and Louvain-la-Neuve, April 28-29, 2009.

Bologna Process. (2012a). Making the most of our potential: Consolidating the European Higher Education Area. Bucharest Communiqué.

Bologna process. (2012b). Meeting of the Bologna Follow-Up Group Copenhagen, 18-19 January 2012. Draft outcome of proceedings, Document BFUG_DK_AZ_29_3b.

Bologna Process. (2014). Report by the Structural Reforms Working Group to the BFUG. Retrieved from http://bologna-yerevan2015.ehea.info/files/Final\%20Report\%20of\%20the\% 20Structural\%20Reforms\%20WG.pdf, on November 2, 2017.

Bologna Process. (2015a). Yerevan Communiqué.

Bologna Process. (2015b). Belarus roadmap for Higher Education reform. Retrieved from http:// bologna-yerevan2015.ehea.info/files/Roadmap\%20Belarus_21.05.2015.pdf, on November 2, 2017.

Bologna Process. (2015c). "Terms of Reference of the Advisory group on Dealing with non-implementation" Document BFUGBoard_NL_MD_49_6d, last modified November 2, 2105. Retrieved from http://www.ehea.info/cid105406/ag-non-implementation-2015-2018. html, on November 2, 2017.

Bologna Process. (2015d). EHEA Ministerial Conference and Fourth Bologna Policy Forum, Yerevan, 14-15 May 2015. Evaluation report. Document BFUGMeeting_LU_LI_48_5, last modified August 24, 2015. Retrieved from http://www.ehea.info/cid105416/bfug-meeting-48. html, on November 2, 2017.

Bologna Process. (2017). BFUG Meeting Bratislava (Slovakia) 8/9 December 2016, document BFUG_SK_ME_52_Minutes, last modified February 21, 2017. Retrieved from https://media. ehea.info/file/20161208-09-Bratislava/00/5/BFUG_SK_ME_52c_Minutes_Bratislava_ 720005.pdf, on November 2, 2017.

Council of Europe. (2007). Recommendation Rec (2007)6 by the Committee of Ministers to member states on the public responsibility for higher education and research. Retrieved July 19, 2017 https://search.coe.int/cm/Pages/result_details.aspx?ObjectId=09000016805d5dae.

Council of Europe/UNESCO. (1997). The Convention on the Recognition of Qualifications concerning Higher Education in the European Region (Lisbon Recognition Convention; European Treaties Series 165). Retrieved November 2, 2017 http://www.coe.int/en/web/ conventions/full-list/-/conventions/treaty/165.

Dang, Q. (2015). The Bologna process goes east? From "Third Countries" to prioritizing Inter-regional Cooperation between ASEAN and EU. In A. Curaj, L. Matei, R. Pricopie, J. Salmi, \& P. Scott (Eds.), The European Higher Education Area: Between critical reflections and future policies (pp. 773-793). Heidelberg: Springer Open Access.

Dang, Q. (2017). An anatomy of authority: the Bologna and ASEM education secretariats as policy actors and region builders. In Globalisation, Societies, and Education, published on line December 8, 2017.

Dang, Q. (present volume). Unintended outcomes of the EHEA and ASEAN: Peripheral members and their façade conformity.

Deca, L. (2016). Understanding the internationalization of higher education as a policy process. The case of Romania PhD thesis, University of Luxembourg. Retrieved from http://hdl.handle. net/10993/31206.

Erdoğan, A. (2015). Current and future prospects for the Bologna process in the Turkish Higher Education System. In A. Curaj, L. Matei, R. Pricopie, J. Salmi, \& P. Scott (Eds.), The European Higher Education Area: Between critical reflections and future policies (pp. 753-772). Heidelberg: Springer Open Access.

European Commission/EACEA/Eurydice. (2015). The European Higher Education Area in 2015: Bologna process implementation report. Luxembourg: Publications Office of the European Union.

European Students' Union. (2015). Overview of student-centred learning in Europe. Research study. Brussels: European Students Union. 
Gallagher, T. (this volume). Promoting the civic and democratic role of higher education: The next challenge for the EHEA?.

Garben, S. M. M. (2011). EU Higher Education Law. The Bologna process and harmonization by stealth. Kluwer Law International.

Gaston, P. L. (2010). The challenge of Bologna. What United States Higher Education has to learn from Europe, and why it matters that we learn it. Sterling, VA: Stylus Publishing.

Harmsen, R. (2015). Future scenarios for the European Higher Education Area: Exploring the possibilities of "Experimentalist Governance". In A. Curaj, L. Matei, R. Pricopie, J. Salmi, \& P. Scott (Eds.), The European Higher Education Area: Between critical reflections and future policies (pp. 795-813). Heidelberg: Springer Open Access.

Kehm, B. M., Huisman, J., \& Stensaker, B. (Eds.). (2009). The European Higher Education Area: Perspectives on a moving target. Rotterdam: Sense Publishers.

Klemenčič, M., Bergan, S., \& Primožič, R. (Eds.). (2015). Student engagement in Europe: Society, higher education and student governance. Strasbourg: Council of Europe Publishing. Council of Europe Higher Education Series No. 20.

Matei, L., \& Iwinska, J. (present volume). Divergent paths? Institutional autonomy and academic freedom in the European Higher Education Area.

PACE. (2009). Recommendation 1892 (2009) by the Parliamentary Assembly of the Council of Europe on the Contribution of the Council of Europe to the development of the European Higher Education Area. Retrieved from http://assembly.coe.int/nw/xml/XRef/XrefXML2HTML-en.asp?fileid=17791\&lang=en, on November 2, 2017.

Santa, R. (this volume). Future of European higher education in an age of demographic headwinds. The impact of demographic decline on higher education system structures and funding in Romania, Poland and Russia.

Strand Viðarsdóttir, Ú. (this volume). Implementation of key commitments and the future of the Bologna process.

Vukasovic, M., Meng-Hsuan, C., Elken, M., Jungblut, J., \& Ravinet, P. (present volume). Multi-level, multi-actor and multi-issue dimensions of governance of the European Higher Education Area, and beyond.

Zgaga, P. (2007). Looking out: The Bologna process in a global setting. On the "External Dimension" of the Bologna process. Oslo: Norwegian Ministry of Education and Research. Retrieved from https://media.ehea.info/file/WG_External_dimension/34/3/ExternalDimension_ report2007_581343.pdf, on November 2, 2017.

Open Access This chapter is licensed under the terms of the Creative Commons Attribution 4.0 International License (http://creativecommons.org/licenses/by/4.0/), which permits use, sharing, adaptation, distribution and reproduction in any medium or format, as long as you give appropriate credit to the original author(s) and the source, provide a link to the Creative Commons license and indicate if changes were made.

The images or other third party material in this chapter are included in the chapter's Creative Commons license, unless indicated otherwise in a credit line to the material. If material is not included in the chapter's Creative Commons license and your intended use is not permitted by statutory regulation or exceeds the permitted use, you will need to obtain permission directly from the copyright holder.

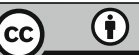

